\title{
Éditorial
}

\section{Numéro 10!}

La revue ETP/TPE, l'organe de la SETE (Société d'éducation scientifique européenne) a atteint son dixième numéro à l'automne 2013 et ceci constitue une étape importante.

En effet, ETP/TPE est aujourd'hui reconnue comme une des rares revues scientifiques internationales consacrées exclusivement à l'éducation du patient. En témoignent des articles publiés dans la revue en provenance de cinq pays européens, d'Amérique du Nord (Canada, USA) et d'Australie. En témoigne également le référencement obtenu très précocement dans de grandes banques de données internationales comme Scopus, CINAHL et Psychinfo. ETP/TPE est aussi, en France, référencée dans la Banque de données en Santé Publique (BDSP) et l'AERES. L'étape suivante consistera à obtenir le référencement dans Medline, puis l'attribution par ISI d'un facteur d'impact, si modeste soit-il au début. Les conditions de référencement dans Medline ont beaucoup changé récemment; les exigences se sont considérablement accrues pour ce qui concerne la politique d'éthique de la revue et les déclarations d'absence de conflit d'intérêt. Pour anticiper ces demandes, nous avons inscrit la revue à une organisation internationale : « $\mathrm{COPE} »$ en charge de la réflexion et des recommandations sur les problèmes d'éthique que rencontrent les journaux scientifiques; d'autre part, les futurs auteurs de ETP/TPE ne devront pas se formaliser de devoir remplir des questionnaires plus longs et plus détaillés sur d'éventuels conflits d'intérêt.

Mais la qualité d'une revue se juge aussi aux articles qu'elle reçoit, qui font l'objet d'une double révision systématique avec obligation pour les auteurs de répondre point par point aux réviseurs; ils sont actuellement 61, dont 26 anglophones, à être sollicités pour analyser les 74 articles que nous avons publiés jusqu'au numéro 9 de la revue. La répartition des articles entre le français et l'anglais qui sont les deux langues de la revue est de 67,6\% pour le français et 32,4\% pour l'anglais; la proportion de ces derniers est passé de $27 \%$ en 2010 à $41 \%$ en 2013.

Sur le plan financier, la revue est depuis deux ans bénéficiaire, en raison du nombre de ses abonnés qui sont actuellement 162, dont 95 institutions. La SETE abonne ses adhérents à la version électronique de la revue et l'IPCEM, les participants à ses formations.

Au départ, nous avions envisagé que la revue proposerait des articles scientifiques sur le premier de ses deux numéros annuels et des descriptions d'expériences et de pratiques sur le second. Les choses ne se sont pas passées ainsi, car la revue reçoit presque exclusivement des articles à caractère scientifique. Toutefois, leur nombre ne nous permet pas d'envisager encore la publication d'un troisième, voire d'un quatrième numéro annuel; il est vrai qu'une récente recension fait état de 1300 articles sur l'éducation thérapeutique publiés en 2012 dans le monde entier, ce qui est finalement très peu. Il faut donc se convaincre que l'éducation thérapeutique est une discipline très nouvelle qui nécessitera encore sans doute des années avant d'asseoir complètement son champ d'investigation dans les multiples directions de la médecine, de la santé publique et des sciences humaines.

Nous sommes convaincus que la revue ETP/TPE jouera un rôle majeur dans ce développement.

JF d'Ivernois 


\section{Editorial}

\section{Number 10!}

ETP/TPE, the official journal of the European Society of Therapeutic Education (SETE), has reached its tenth issue in autumn 2013. This is an important step.

Indeed, ETP/TPE is now considered as one of the few international journals exclusively devoted to patient education. Having published articles from five European countries (France, Switzerland, Belgium, Italy, Netherland), North America (Canada, USA) and Australia, it has been very early referenced in some major international databases such as Scopus, CINAHL and Psychinfo. ETP/TPE is also referenced, in France, in the Public Health (BDSP) and in the AERES databases. The next step will be to be cited in Medline and the attribution, by ISI, of an impact factor, even if low in the early days. Conditions for referencing Medline have recently changed a lot; the requirements have increased considerably with regard to the ethics policy of the journal and the statement of absence of conflict of interest. To anticipate these requests, we recorded the journal to an international organization, "COPE", in charge of thinking over the ethical problems faced by scientific journals and diffusing recommendations. Therefore, in the future, the author submitting a paper to ETP/TPE should not resent having to complete longer and more detailed questionnaires on potential conflicts of interest.

The quality of a journal also depends on the articles received, which are systematically reviewed by two experts to whom the authors have to answer point by point; 61 reviewers, 26 English-speaking, have been asked to analyze the 74 articles published in the 9 issues of the journal. The distribution of the studies between the two languages of the journal, French and English, is 67.6\% articles written into French and 32.4\% into English; the number of the latter increased from 27\% in 2010 to $41 \%$ in 2013.

As regards the economic aspects, the journal is beneficial since two years, thanks to the number of subscribers that are currently 162; 95 among them are institutions. The members of the SETE and of the "Institut pour la Communication en MédecineIPCEM" subscribe to the electronic version of the journal.

Initially, we considered that the journal would propose scientific articles on its first of two annual issues and descriptions of experiences and best practices in TPE on the following second. Things did not go as we thought since the journal receives almost exclusively scientific articles. However, the number of articles submitted still does not allow to expect the publication of a third or a fourth annual issue. Indeed, a recent review reported that 1300 patient education articles were published in 2012 in the world, which can be considered a very small number. We have to be aware that patient education is a very new discipline and therefore that it still requires years to fully be established as field of research in medicine, public health and human sciences.

We believe that the journal ETP/TPE will play a major role in this development.

JF d'Ivernois 